\title{
Historical Note
}

\section{European \\ Neurology}

\section{Burdach's Column}

\author{
J.M.S. Pearce \\ Emeritus Consultant Neurologist, Department of Neurology, Hull Royal Infirmary, Hull, UK
}

\section{Key Words}

Spinal cord anatomy · Benedikt Stilling •

Burdach's column · Posterior columns

\begin{abstract}
After the Greek physicians Herophilus and Galen, the major anatomical advances in the anatomy of the spinal cord were made possible by the microtome devised by Benedikt Stilling in January 1842. This enabled him to cut the frozen, thin sections and examine them, unstained, with the microscope. The technique founded future investigation of the cord's anatomy. Brown-Séquard, Türck, Clarke, Lissauer, Goll, and Flechsig all contributed. An important result of these progressing anatomical experiments was the identification of the posterior columns. In 1826, the German physiologist Karl Friedrich Burdach (1776-1847) described, from macroscopic study, the fasciculus cuneatus, known as the tract of Burdach: the lateral portion of the posterior columns of the cord that terminate in the nucleus cuneatus of the medulla.

Copyright @ 2006 S. Karger AG, Basel
\end{abstract}

The Hippocratic physician, Herophilus (325-260 BC) was born in Chalcedon and worked at the Alexandrian School of Medicine. He first demonstrated the caudal extension of the hindbrain, naming it the 'spinal cord', and stated that 'the neura that make voluntary motion possible have their origin in the cerebrum (enkephalos) and spinal marrow'.

\section{KARGER \\ Fax +4161306 1234 \\ E-Mail karger@karger.ch}

www.karger.com
(C) 2006 S. Karger AG, Basel

0014-3022/06/0553-0179\$23.50/0

Accessible online at:

www.karger.com/ene
Galen (130-200 AD) described: 'the cord like a river rising from its source, extended from the brain, continuously sending forth a nerve channel to each of the parts that it meets, through which both sensation and motion are conveyed ...'

After the dark ages, Vesalius echoed Galen, but added little new. Gerard Blasius (1625-1692), a Dutch anatomist, in his Anatome Medullae Spinalis Nervorum (1666), demonstrated the anterior and posterior spinal roots and separated the grey and white matter of the cord [1]. Some 40 years later, in 1709, Domenico Mistichelli (16751715) from Pisa showed the pyramidal decussation [2-4].

Francois Pourfour du Petit (1664-1741) also described the decussation of the pyramids and related it to contralateral motor paralysis of brain lesions in $1710[2,4]$. He gave a brief but accurate account of the cord's internal structure. The Swiss anatomist, Johann Jacob Huber (1707-1778) gave the first accurate description of the cord, its division into columns, its spinal roots and denticulate ligaments, in De medulla spinalis speciatim de nervis ab ea provenientibus commentatio cum adjunctis iconibus (Göttingen, 1741). Four distinct columnar divisions, separated by sulci, with grey and white matter conforming to the letter ' $\mathrm{H}$ ' were described by Vicq d'Azyr (1748-1794). In 1809, Rolando described the substantia gelatinosa.

The crucial advance was from naked eye to microscopic examination; it was made possible by the invaluable tool, the microtome devised by Benedikt Stilling (1810-1879) in January 1824. This enabled him to cut the frozen, or alcohol-hardened spinal cord into thin sections 
and examine them, unstained, with the microscope. The technique founded future investigation of the cord's anatomy. In 1846, Brown-Séquard showed the decussation of the sensory tracts. Then followed several studies [2] concerned with the position and course of the different tracts or fasciculi in the cord by Burdach (1826), Türck (1849), Clarke (1851), Lissauer (1855), Goll (1860), and Flechsig (1877-1878).

An important result of these progressing anatomical experiments was the demonstration of the posterior columns. In 1826, the German physiologist Karl Friedrich Burdach (1776-1847) described, from macroscopic study, the fasciculus cuneatus, known as the tract of Burdach [5]. It is the lateral portion of the posterior columns of the spinal cord, consisting of ascending fibres that terminate in the nucleus cuneatus of the medulla oblongata. The tract of Burdach comprises fibres that are shorter, but larger than those of the fasciculus gracilis (tract of Friedrich Goll). Both tracts are extensions of the same posterior roots. Some fibres ascend for a short distance, then enter the grey matter close to Clarke's posterior vesicular column; others pass medially to form the column of Goll [6] and ascend to the medulla. Friedrich Goll (18291903) was a Swiss anatomist who studied in Würzburg and Paris. He worked in Zurich and taught pathology and materia medica.

\section{Karl Friedrich Burdach}

Burdach was born in Leipzig and died in Königsberg [7]. He was the only child of Daniel Christian Burdach, who practised medicine in Leipzig until an early death. Karl studied Medicine in his native town obtaining his doctorate in 1797. To further his education, he went to Vienna but returned to Leipzig at the age of 23. Burdach, who was fascinated by Schelling's natural philosophy, published widely during this period.

He became lecturer at Leipzig University (1799-1811). Burdach is credited with the name biology to denote the study of human morphology, physiology and psychology.

After unsuccessful applications, he was appointed to the Chair of Anatomy, Physiology and Forensic Medicine in Dorpat (now Tartu), Estonia in 1811. There he influenced the brilliant polymath, Karl Ernst Ritter von Baer (1792-1876), who discovered the mammalian ovum, the notochord and established the new science of comparative embryology alongside comparative anatomy.

Burdach, at last financially independent, concentrated his energies on embryology. In 1814 , he was invited to Königsberg as Professor of Anatomy. There he founded the anatomical institute, and was its director until 1826. His pro-rectors were von Baer and Rathke, who later achieved distinction in embryological anatomy. In 1822, Burdach named the cingulate gyrus.

Burdach's greatest contribution to science was his handbook Die Physiologie als Erfahrungswissenschaft (Physiology as a science of experience) [8]. Whilst preparing this work, he established contacts with numerous researchers in many branches of the natural sciences. His significant contributions to embryology and neuroanatomy reveal the influences of Naturphilosophie. Die Physiologie als Erfahrungswissenschaft was intended to appraise every factor influencing life, but the sections on movement, sensation and the activity of the soul were never published. An indication of his broad interests is shown in a letter from Sir Henry Holland to Charles Darwin (10 February 1863) [9] that cites (C.F.?) 'Burdach as the source of a note on atavism in alternate generations'.

\section{References}

1 Von Staden H: Herophilus: The Art of Medicine in Early Alexandria. New York, Cambridge University Press, 1989.

2 Clarke E, O'Malley CD: The Human Brain and Spinal Cord: A Historical Study, ed 2. San Francisco, Norman, 1996, pp 260-289.

3 Finger S: Origins of Neuroscience: A History of Explorations into Brain Function. New York, Oxford University Press, 1994.
4 McHenry LC Jr: Garrison's History of Neurology. Springfield, Charles C. Thomas, 1969, pp 3-24.

5 Burdach KF: Vom Baue und Leben des Gehirns. Leipzig, Dyk, 3 vols, 1819-1826.

6 Goll F: Beiträge zur feineren Anatomie des menschlichen Rückenmarks. Inaugural Dissertation der Medizinischen Fakultät Zürich. Zürich, 1860, pp 130-171.
7 Picard HB: K.F. Burdach's work and philosophy. Med Monatsschr 1951;5:125-128.

8 Meyer A: Karl Friedrich Burdach and his place in the history of neuroanatomy. J Neurol Neurosurg Psychiatry 1970;33:553-561.

9 The Darwin Correspondence Online Database. http://darwin.lib.cam.ac.uk/perl/nav?pclass= name;pkey=Burdach $\% 2 \mathrm{C} \% 20 \mathrm{~K} . \% 20 \mathrm{~F}$. 